Phosphorus Research Bulletin Vol. 18 (2005), 37-46

\title{
MECHANOCHEMICAL EFFECTS ON FORMATION AND PROPERTIES OF VARIOUS COPPER PHOSPHATES
}

\section{HIROAKI ONONA ${ }^{a,},{ }^{*}$ KAZUO KOJIMA ${ }^{a}$, AND HIROYUKI NARIAI ${ }^{b}$}

a Department of Applied Chemistry, Faculty of Science and Engineering, Ritsumeikan University, 1-1-1, Nojihigashi, Kusatsu, Shiga 525-8577, Japan

b Department of Molecular Science and Materials Engineering, Graduate School of Science and Technology, Kobe University, 1-1, Rokkodai-cho, Nada-ku, Kobe 657-8501, Japan

* onoda@se.ritsumei.ac.jp

\begin{abstract}
The mixtures of $\mathrm{NH}_{4} \mathrm{H}_{2} \mathrm{PO} 4$ and $\mathrm{CuCO}_{3} \cdot \mathrm{Cu}(\mathrm{OH}) 2 \cdot \mathrm{H}_{2} \mathrm{O}$ in the molar ratio $\mathrm{P} / \mathrm{Cu}=2 / 3,1 / 1$, and $2 / 1$ were milled with planetary mill for several minutes. Copper oxide, $\mathrm{CuO}$, was used in the same manner as basic copper carbonate. Then thermal behavior of these mixtures was analyzed by differential thermal analyses, X-ray diffraction, and Fourier transform infrared spectroscopy. The thermal products were estimated by ultraviolet - visible reflectance spectra, particle size distribution, and the amount of adsorbed nitrogen gas.
\end{abstract}

\section{INTRODUCTION}

Phosphates are transformed to other phosphates in hydrolysis and dehydration reactions at elevated temperatures. ${ }^{1-6}$ There are polyphosphate, cyclo-phosphate, and ultraphosphate in a group of condensed phosphates. Polyphosphate has a chain structure in which $\mathrm{PO} 4$ unit shares two oxygen atoms, cyclo-phosphate has a cyclic structure, and ultraphosphate has a network structure. ${ }^{7}$

Phosphates have been used for ceramic materials, catalysts, fluorescent materials, metal surface treatment, detergent, pigments, etc. In general, inorganic phosphate pigments are prepared from the processes of mixing of starting materials, calcination, crushing, examination, and adjusting their color in order. Up

Received August 30, 2004; Accepted October 22, 2004 
to now, there are some reports about calcination temperature and time, however less report about mixing of starting materials. Because particle shape and size distribution have influence on the color of pigments, the study about mixing process of starting materials is important for development of new inorganic functional materials.

Physical and chemical properties of solid materials are changed by crusing, pressing, milling, and other mechanical treatments. ${ }^{8-14}$ These phenomena are known as mechanochemical effects, which comprises of the increase of specific surface area, defects and strain, and the cleavage of chemical bonds, and so on. For these effects, mechanically treated materials are regarded as in an active state. These mechanical treatments have been applied to inorganic materials. By using these mechanical treatments, new materials has tried to be synthesized, higher yields of products and sintering effect at lower temperature could be expected.

In previous work, mechanochemical effects were investigated in formation of manganese pyrophosphate. ${ }^{15}$ In the system, since the mixed materials were activated as mechanochemical effects, $\mathrm{Mn} 2 \mathrm{P} 2 \mathrm{O} 7$ was formed at lower temperature. During mechanical treatment, the change of hue was observed at lower temperature and phosphates had a more vivid tone. Mechanochemical treatment on starting materials was effective method for formation of functional inorganic materials.

In this work, mechanochemical effects were studied on formation of various copper phosphates from ammonium dihydrogenphosphate and basic copper carbonate and from ammonium dihydrogenphosphate and copper oxide, and their properties.

\section{EXPERIMENTAL}

The mixtures of ammonium dihydrogenphosphate, $\mathrm{NH} 4 \mathrm{H} 2 \mathrm{PO} 4$, and basic copper carbonate, $\mathrm{CuCO}_{3} \cdot \mathrm{Cu}(\mathrm{OH}) 2 \cdot \mathrm{H} 2 \mathrm{O}$, in the molar ratio $\mathrm{P} / \mathrm{Cu}=2 / 3,1 / 1$, and $2 / 1$ were milled with planetary mill for several minutes. The planetary mill was with five ball $(15 \mathrm{~mm}$ diameter, $\mathrm{ZrO} 2)$ and a pot $(40 \mathrm{~mm}$ inside diameter, $40 \mathrm{~mm}$ depth, $\mathrm{ZrO} 2$ ) from FRITSCH Ltd. Copper oxide, $\mathrm{CuO}$, was used in the same 
manner as basic copper carbonate. Then thermal behavior of these mixtures was analyzed by differential thermal analyses (DTA), X-ray diffraction (XRD), and Fourier transform infrared spectroscopy (FT-IR). DTA were measured with a Rigaku Denki DTA50. Thermal analyses were carried out at $10^{\circ} \mathrm{C} / \mathrm{min}$. XRD patterns were recorded on a Rigaku Denki RINT 2000M X-Ray diffractometer using monochromated $\mathrm{CuK} \alpha$ radiation. The IR spectra were recorded on a Shimadzu FT-IR spectrometer FT-IR8600 with a KBr disk method.

The thermal products heated at several temperatures for 1 hour were estimated by ultraviolet - visible (UV-Vis) reflectance spectra, particle size distribution, and the amount of adsorbed nitrogen gas. UV-Vis reflectance spectra were measured with a Shimadzu UV365. Particle size distribution was measured with laser diffraction/scattering particle size distribution HORIBA LA-910. Specific surface areas of phosphates were calculated from the amount of nitrogen gas adsorbed at the temperature of liquid nitrogen by BET method with Belsorp mini from BEL JAPAN, INC.

\section{RESULTS AND DISCUSSION}

\section{Products in $\mathrm{P} / \mathrm{Cu}=2 / 3$}

Figure 1 shows DTA curves of samples prepared from $\mathrm{NH}_{4} \mathrm{H}_{2} \mathrm{PO}_{4}$ and $\mathrm{CuCO}_{3} \cdot \mathrm{Cu}(\mathrm{OH}) 2 \cdot \mathrm{H}_{2} \mathrm{O}$ in $\mathrm{P} / \mathrm{Cu}=2 / 3$ milled for several minutes. All samples had an endothermic peak at about $200^{\circ} \mathrm{C}$. This peak was considered to be due to volatilization of ammonia. DTA curve of sample without milling (Fig. 1(a)) had an endothermic peak at $290^{\circ} \mathrm{C}$. By mechanical treatment, some exothermic peaks appeared above $280^{\circ} \mathrm{C}$, especially an exothermic peak at $570^{\circ} \mathrm{C}$

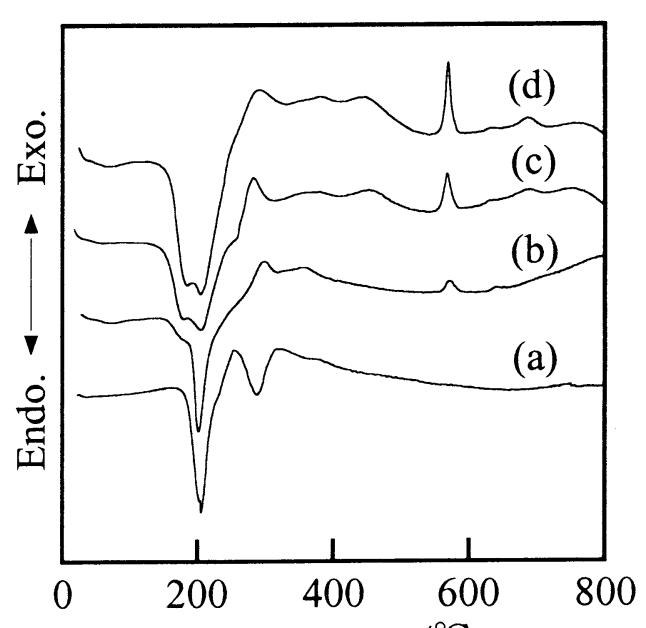

Temperature $/{ }^{\circ} \mathrm{C}$

FIGURE 1. DTA curves of samples prepared from $\mathrm{NH} 4 \mathrm{H}_{2} \mathrm{PO} 4$ and $\mathrm{CuCO} 3 \cdot \mathrm{Cu}(\mathrm{OH}) 2 \cdot \mathrm{H} 2 \mathrm{O}$ in $\mathrm{P} / \mathrm{Cu}=2 / 3$ milled for several minutes, (a) $0 \mathrm{~min}$, (b) $10 \mathrm{~min}$, (c) $20 \mathrm{~min}$, and (d) $30 \mathrm{~min}$. 
became larger with milling time.

Samples without heating had XRD patterns of starting materials, $\mathrm{NH}_{4} \mathrm{H}_{2} \mathrm{PO} 4$ and $\mathrm{CuCO}_{3} \cdot \mathrm{Cu}(\mathrm{OH}) 2 \cdot \mathrm{H}_{2} \mathrm{O}$. The weak peaks of $\mathrm{CuO}$ were observed in $\mathrm{XRD}$ pattern of sample without milling at $250^{\circ} \mathrm{C}$, on the other hand, milled samples at $250^{\circ} \mathrm{C}$ were amorphous phase. Samples without milling and milled for $10 \mathrm{~min}$ at 350 and $500^{\circ} \mathrm{C}$ had broad $\mathrm{XRD}$ peaks of $\mathrm{CuO}$ and $\mathrm{Cu}_{2} \mathrm{P} 2 \mathrm{O} 7$. The sample milled for $10 \mathrm{~min}$ had weaker peaks than the sample without milling. Samples milled for 20 and $30 \mathrm{~min}$ and then heated at 350 and $500^{\circ} \mathrm{C}$ were amorphous phase from XRD analyses. At $600^{\circ} \mathrm{C}$, sample without milling had XRD peaks of $\mathrm{CuO}$ and $\mathrm{Cu}_{2} \mathrm{P}_{2} \mathrm{O} 7$, sample milled for $10 \mathrm{~min}$ had weak peaks of $\mathrm{Cu}_{2} \mathrm{P} 2 \mathrm{O} 7$ and $\mathrm{Cu} 3(\mathrm{PO} 4) 2$, and samples milled for 20 and $30 \mathrm{~min}$ had weak peaks of $\mathrm{Cu} 3(\mathrm{PO} 4) 2$. Figure 2 shows XRD patterns of samples prepared from $\mathrm{NH}_{4} \mathrm{H}_{2} \mathrm{PO} 4$ and $\mathrm{CuCO}_{3} \cdot \mathrm{Cu}(\mathrm{OH}) 2 \cdot \mathrm{H}_{2} \mathrm{O}$ in $\mathrm{P} / \mathrm{Cu}=2 / 3$ milled for several minutes and then heated at $700^{\circ} \mathrm{C}$. Sample without milling (Fig. 2(a)) had XRD patterns of $\mathrm{Cu}_{2} \mathrm{P}_{2} \mathrm{O} 7$ and $\mathrm{CuO}$, on the other hand, samples milled for 20 and $30 \mathrm{~min}$ had XRD patterns of $\mathrm{Cu} 3(\mathrm{PO} 4) 2$ (Fig. 2(c)(d)). The endothermic peak at $290^{\circ} \mathrm{C}$ in DTA curve of sample without milling (Fig. 1(a)) was considered to be due to dehydration condensation

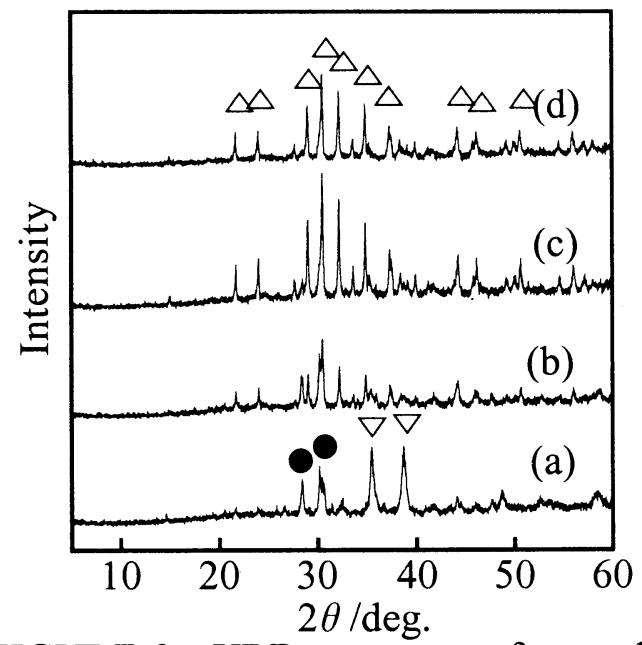

FIGURE 2. XRD patterns of samples prepared from $\mathrm{NH}_{4} \mathrm{H}_{2} \mathrm{PO} 4$ and $\mathrm{CuCO}_{3} \cdot \mathrm{Cu}(\mathrm{OH}) 2 \cdot \mathrm{H}_{2} \mathrm{O}$ in $\mathrm{P} / \mathrm{Cu}=2 / 3$ milled for several minutes and then heated at $700^{\circ} \mathrm{C}$, (a) $0 \mathrm{~min}$, (b) $10 \mathrm{~min}$, (c) $20 \mathrm{~min}$, and (d) $30 \mathrm{~min}, \nabla ; \mathrm{CuO}$, ; $\mathrm{Cu}_{2} \mathrm{P}_{2} \mathrm{O} 7$, and $\triangle ; \mathrm{Cu}_{3}\left(\mathrm{PO}_{4}\right) 2$.

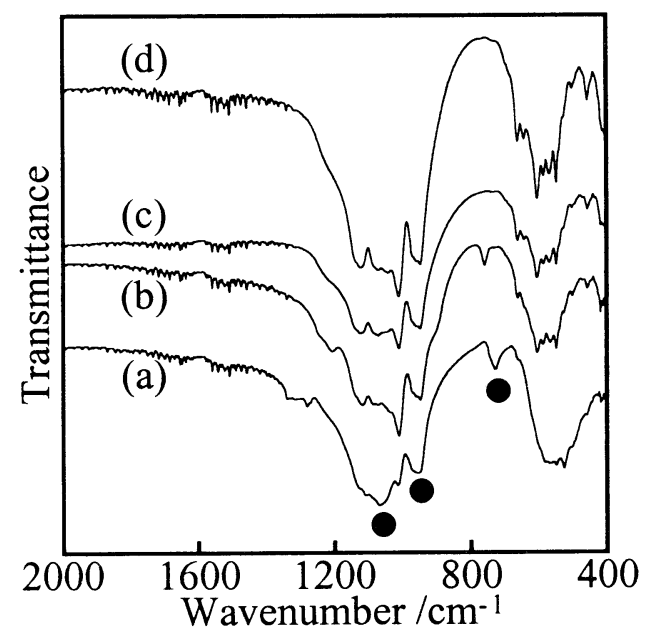

FIGURE 3. IR spectra of samples prepared from $\mathrm{NH} 4 \mathrm{H}_{2} \mathrm{PO} 4$ and $\mathrm{CuCO}_{3} \cdot \mathrm{Cu}(\mathrm{OH}) 2 \cdot \mathrm{H}_{2} \mathrm{O}$ in $\mathrm{P} / \mathrm{Cu}=2 / 3$ milled for several minutes and then heated at $600^{\circ} \mathrm{C}$, (a) $0 \mathrm{~min}$, (b) $10 \mathrm{~min}$, (c) $20 \mathrm{~min}$, and (d) $30 \mathrm{~min}$, $\mathrm{Cu} 2 \mathrm{P} 2 \mathrm{O} 7$. 
of phosphates. In this reaction, copper pyrophosphate was formed, and remained $\mathrm{CuCO}_{3} \cdot \mathrm{Cu}(\mathrm{OH}) 2 \cdot \mathrm{H} 2 \mathrm{O}$ transformed to $\mathrm{CuO}$.

Figure 3 shows IR spectra of samples prepared from $\mathrm{NH}_{4} \mathrm{H}_{2} \mathrm{PO} 4$ and $\mathrm{CuCO}_{3}$. $\mathrm{Cu}(\mathrm{OH}) 2 \cdot \mathrm{H}_{2} \mathrm{O}$ in $\mathrm{P} / \mathrm{Cu}=2 / 3$ milled for several minutes and then heated at $600^{\circ} \mathrm{C}$. The absorption peaks at about 1070,950 , and $730 \mathrm{~cm}^{-1}$ were observed in IR spectrum of sample without milling (Fig. 3(a)). These peaks were due to copper pyrophosphate. 16 IR spectra of samples heated at $600^{\circ} \mathrm{C}$ changed by mechanical treatment. Especially, the absorption peak at about $730 \mathrm{~cm}^{-1}$ was disappeared in IR spectra of samples milled for 20 and $30 \mathrm{~min}$ (Fig. 3(c)(d)). It was considered that pyrophosphate wasn't formed in samples milled for 20 and 30 min. Milled samples heated at $600^{\circ} \mathrm{C}$ (Fig. 3(b)(c)(d)) had IR spectra of orthophosphate. From the results of XRD patterns and IR spectra, the exothermic peak at $570^{\circ} \mathrm{C}$ in DTA curves of milled samples (Fig. 1(b)(c)(d)) was considered to be due to crystallization of $\mathrm{Cu} 3(\mathrm{PO} 4) 2$. The exothermic peaks at $280 \sim 460^{\circ} \mathrm{C}$ in DTA curves of milled samples were thought to be due to reaction between $\mathrm{NH} 4 \mathrm{H}_{2} \mathrm{PO} 4$ and $\mathrm{CuCO}_{3} \cdot \mathrm{Cu}(\mathrm{OH}) 2 \cdot \mathrm{H}_{2} \mathrm{O}$ to low crystallized $\mathrm{Cu}_{3}(\mathrm{PO} 4) 2$.

Mechanochemical treatment in the system of $\mathrm{NH}_{4} \mathrm{H}_{2} \mathrm{PO} 4$ and $\mathrm{CuCO}_{3} \cdot \mathrm{Cu}(\mathrm{OH}) 2 \cdot \mathrm{H}_{2} \mathrm{O}$ in $\mathrm{P} / \mathrm{Cu}=2 / 3$ made thermal products change from the mixture of $\mathrm{Cu}_{2} \mathrm{P}_{2} \mathrm{O} 7$ and $\mathrm{CuO}$ to $\mathrm{Cu} 3(\mathrm{PO} 4) 3$. This was considered that starting mixture was homogenized and activated by mechanochemical treatment.

\section{Products in $\mathrm{P} / \mathrm{Cu}=1 / 1$}

An endothermic peak at about $200^{\circ} \mathrm{C}$ was observed in DTA curves of all samples in $\mathrm{P} / \mathrm{Cu}=1 / 1$. This peak was considered to be due to volatilization of $\mathrm{NH}$ 3. Some small exothermic peaks were observed above $270^{\circ} \mathrm{C}$ and changed by mechanical treatment. Figure 4 shows XRD patterns of samples prepared from $\mathrm{NH} 4 \mathrm{H}_{2} \mathrm{PO} 4$ and $\mathrm{CuCO} 3 \cdot \mathrm{Cu}(\mathrm{OH}) 2 \cdot \mathrm{H} 2 \mathrm{O}$ in $\mathrm{P} / \mathrm{Cu}=1 / 1$ milled for several minutes and then heated at $500^{\circ} \mathrm{C}$. Sample without milling had XRD peaks of $\mathrm{CuH}_{2} \mathrm{P} 2 \mathrm{O} 7$ and $\mathrm{Cu}_{2} \mathrm{P}_{2} \mathrm{O} 7$ (Fig. 4(a)). By mechanical treatment, the intensity of peaks of $\mathrm{Cu}_{2} \mathrm{P}_{2} \mathrm{O}_{7}$ became strong and the intensity of peaks of $\mathrm{CuH}_{2} \mathrm{P}_{2} \mathrm{O}_{7}$ became weak. Samples heated at $700^{\circ} \mathrm{C}$ had $\mathrm{XRD}$ pattern of $\mathrm{Cu} 2 \mathrm{P} 2 \mathrm{O} 7$ in spite of milling time 
(not shown). Figure 5 shows IR spectra of samples prepared from $\mathrm{NH} 4 \mathrm{H} 2 \mathrm{PO} 4$ and $\mathrm{CuCO} 3 \cdot \mathrm{Cu}(\mathrm{OH}) 2 \cdot \mathrm{H} 2 \mathrm{O}$ in $\mathrm{P} / \mathrm{Cu}=1 / 1$ milled for several minutes and then heated at $500^{\circ} \mathrm{C}$. All samples had the absorption peak at about $760 \mathrm{~cm}^{-1}$ due to pyrophosphate anion, $\mathrm{P}_{2} \mathrm{O}^{4}$-. However, samples without milling and milled for 10 minutes had different IR spectra with samples milled for 20 and 30 minutes. A certain degree of orthophosphate was considered to be remained. Mechanical treatment for 20 minutes made thermal product at $500^{\circ} \mathrm{C}$ changed. At $700^{\circ} \mathrm{C}$, all samples indicated IR spectrum of $\mathrm{Cu} 2 \mathrm{P} 2 \mathrm{O} 7$ (not shown).

In $\mathrm{P} / \mathrm{Cu}=1 / 1$ which is corresponding to $\mathrm{Cu} 2 \mathrm{P} 2 \mathrm{O} 7$, thermal product at $500^{\circ} \mathrm{C}$ was changed from the mixture of $\mathrm{CuH}_{2} \mathrm{P}_{2} \mathrm{O}_{7}$ and $\mathrm{Cu}_{2} \mathrm{P}_{2} \mathrm{O}_{7}$ to $\mathrm{Cu}_{2} \mathrm{P}_{2} \mathrm{O}_{7}$ as mechanochemical effects. Mechanical treatment on starting materials from $\mathrm{NH} 4 \mathrm{H}_{2} \mathrm{PO} 4$ and $\mathrm{CuCO}_{3} \cdot \mathrm{Cu}(\mathrm{OH}) 2 \cdot \mathrm{H}_{2} \mathrm{O}$ in $\mathrm{P} / \mathrm{Cu}=1 / 1$ was effective method for formation of homogenous $\mathrm{Cu}_{2} \mathrm{P} 2 \mathrm{O} 7$ at lower temperature.

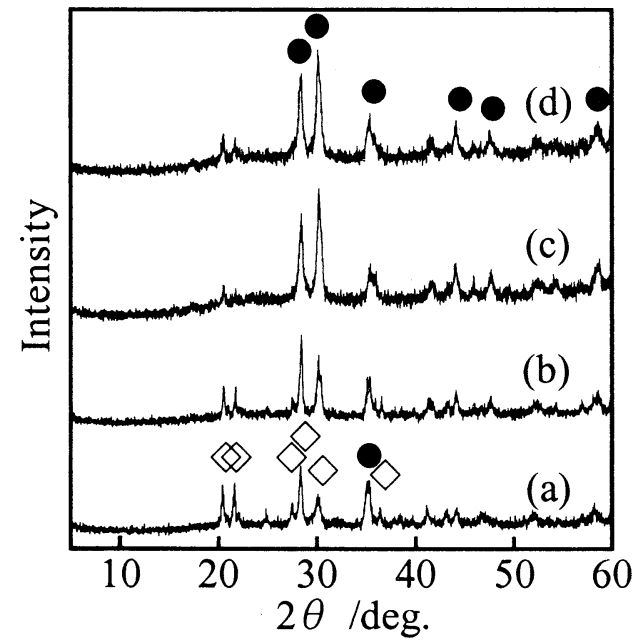

FIGURE 4. XRD patterns of samples prepared from $\mathrm{NH}_{4} \mathrm{H}_{2} \mathrm{PO} 4$ and $\mathrm{CuCO} 3 \cdot \mathrm{Cu}(\mathrm{OH}) 2 \cdot \mathrm{H} 2 \mathrm{O}$ in $\mathrm{P} / \mathrm{Cu}=1 / 1$ milled for several minutes and then heated at $500^{\circ} \mathrm{C}$, (a) $0 \mathrm{~min}$, (b) $10 \mathrm{~min}$, (c) $20 \mathrm{~min}$, and (d) $30 \mathrm{~min}, \diamond$; $\mathrm{CuH}_{2} \mathrm{P}_{2} \mathrm{O} 7$ and $\mathrm{Cu} 2 \mathrm{P} 2 \mathrm{O} 7$.

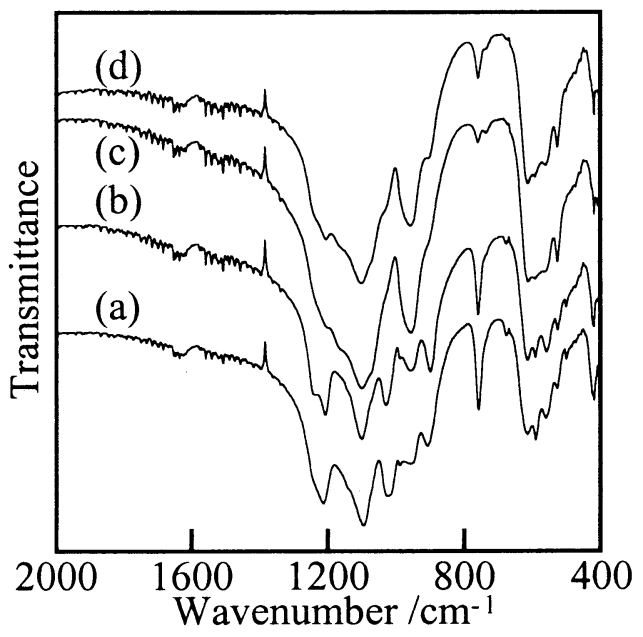

FIGURE 5. IR spectra of samples prepared from $\mathrm{NH} 4 \mathrm{H}_{2} \mathrm{PO} 4$ and $\mathrm{CuCO} 3 \cdot \mathrm{Cu}(\mathrm{OH}) 2 \cdot \mathrm{H}_{2} \mathrm{O}$ in $\mathrm{P} / \mathrm{Cu}=1 / 1$ milled for several minutes and then heated at $500^{\circ} \mathrm{C}$, (a) $0 \mathrm{~min}$, (b) $10 \mathrm{~min}$, (c) $20 \mathrm{~min}$, and (d) $30 \mathrm{~min}$.

Products in $\mathrm{P} / \mathrm{Cu}=2 / 1$

All samples in $\mathrm{P} / \mathrm{Cu}=2 / 1$ had an endothermic peak at about $205^{\circ} \mathrm{C}$ due to 
volatilization of $\mathrm{NH}$. DTA curves of milled samples had noisy endothermic peak at about $350^{\circ} \mathrm{C}$. The blurring of DTA curves was sometimes observed in the measurements of samples which had rich ratio of phosphorus / cation.

Figure 6 shows XRD patterns of samples prepared from $\mathrm{NH}_{4} \mathrm{H}_{2} \mathrm{PO} 4$ and $\mathrm{CuCO} 3 \cdot \mathrm{Cu}(\mathrm{OH}) 2 \cdot \mathrm{H}_{2} \mathrm{O}$ in $\mathrm{P} / \mathrm{Cu}=2 / 1$.

Sample without milling at $250^{\circ} \mathrm{C}$ (Fig. 6(a)) had weak peaks of $\mathrm{Cu}_{2} \mathrm{P} 2 \mathrm{O} 7$ and milled samples at $250^{\circ} \mathrm{C}$ (for example Fig. 6(b)) had weak unknown peaks. Samples heated at $400^{\circ} \mathrm{C}$ had XRD pattern of $\mathrm{Cu}_{2} \mathrm{P} 4 \mathrm{O} 12$ in spite of milling time (Fig. 6(c)(d)). The endothermic peak at about $350^{\circ} \mathrm{C}$ in DTA curves of milled samples was considered to be due to formation of $\mathrm{Cu} 2 \mathrm{P} 4 \mathrm{O} 12$ by dehydration condensation. Mechanical treatment in the system at $\mathrm{P} / \mathrm{Cu}=2 / 1$ had influence on formation process of $\mathrm{Cu} 2 \mathrm{P} 4 \mathrm{O} 12$.

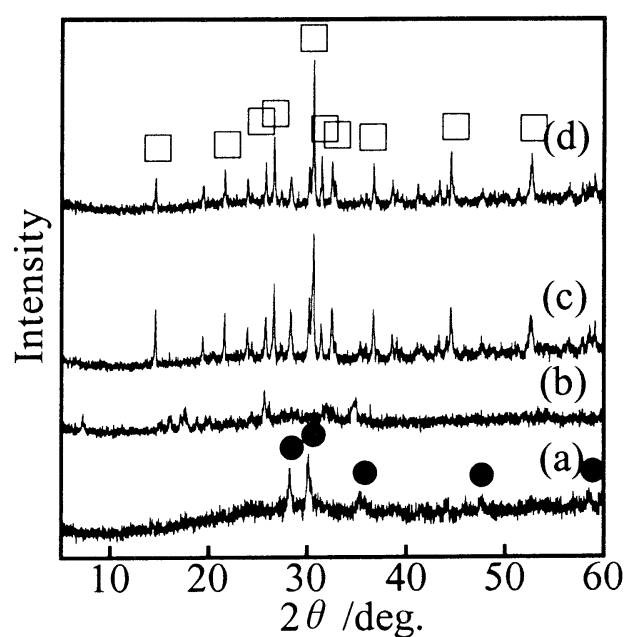

FIGURE 6. XRD patterns of samples prepared from $\mathrm{NH} 4 \mathrm{H} 2 \mathrm{PO} 4$ and $\mathrm{CuCO}_{3} \cdot \mathrm{Cu}(\mathrm{OH}) 2 \cdot \mathrm{H}_{2} \mathrm{O}$ in $\mathrm{P} / \mathrm{Cu}$ $=2 / 1$, (a) $0 \mathrm{~min}, 250^{\circ} \mathrm{C}$, (b) $30 \mathrm{~min}$, $250^{\circ} \mathrm{C}$, (c) $0 \mathrm{~min}, 400^{\circ} \mathrm{C}$, and (d) 30 $\min , 400^{\circ} \mathrm{C}, \mathrm{O} ; \mathrm{Cu}_{2} \mathrm{P} 2 \mathrm{O} 7$ and $\square$; $\mathrm{Cu} 2 \mathrm{P} 4 \mathrm{O} 12$.

\section{Products in $\mathrm{P} / \mathrm{Cu}=1 / 1$ from $\mathrm{CuO}$}

DTA curves of samples prepared from $\mathrm{NH} 4 \mathrm{H} 2 \mathrm{PO} 4$ and $\mathrm{CuO}$ in $\mathrm{P} / \mathrm{Cu}=1 / 1$ had endothermic peaks at about 205,300 , and $390^{\circ} \mathrm{C}$ in spite of milling time. Samples without heating had XRD peaks of starting materials, $\mathrm{NH}_{4} \mathrm{H}_{2} \mathrm{PO} 4$ and $\mathrm{CuO}$, and samples heated at $250^{\circ} \mathrm{C}$ had XRD pattern of $\mathrm{CuO}$ in spite of milling time. The endothermic peak at $205^{\circ} \mathrm{C}$ was considered to be due to volatilization of $\mathrm{NH}$. XRD patterns and IR spectra of $\mathrm{Cu}_{2} \mathrm{P}_{2} \mathrm{O}_{7}$ were observed in samples heated at $350^{\circ} \mathrm{C}$ regardless of mechanical treatment. The endothermic peak at $300^{\circ} \mathrm{C}$ was considered to be due to formation of $\mathrm{Cu}_{2} \mathrm{P} 2 \mathrm{O} 7$ by dehydration condensation. DTA curve of sample prepared from $\mathrm{NH}_{4} \mathrm{H}_{2} \mathrm{PO} 4$ and $\mathrm{CuCO} 3 \cdot \mathrm{Cu}(\mathrm{OH}) 2 \cdot \mathrm{H} 2 \mathrm{O}$ in $\mathrm{P} / \mathrm{Cu}=2 / 3$ without milling (Fig. 1(a)) also had an endothermic peak at about $300^{\circ} \mathrm{C}$ due to formation of $\mathrm{Cu}_{2} \mathrm{P} 2 \mathrm{O} 7$. However, DTA 
curves of samples prepared from $\mathrm{NH} 4 \mathrm{H} 2 \mathrm{PO} 4$ and $\mathrm{CuCO}_{3} \cdot \mathrm{Cu}(\mathrm{OH}) 2 \cdot \mathrm{H} 2 \mathrm{O}$ in $\mathrm{P} / \mathrm{Cu}$ $=1 / 1$ didn't have an endothermic peak at about $300^{\circ} \mathrm{C}$ due to formation of $\mathrm{Cu}_{2} \mathrm{P} 2 \mathrm{O} 7$. The system of $\mathrm{NH}_{4} \mathrm{H}_{2} \mathrm{PO} 4$ and $\mathrm{CuCO}_{3} \cdot \mathrm{Cu}(\mathrm{OH}) 2 \cdot \mathrm{H}_{2} \mathrm{O}$ in $\mathrm{P} / \mathrm{Cu}=1 / 1$ had a possibility of exothermic reaction at same range of temperature. Samples heated at 500 and $700^{\circ} \mathrm{C}$ had XRD peaks and stronger IR absorption peaks of $\mathrm{Cu} 2 \mathrm{P} 2 \mathrm{O} 7$ than samples heated at $350^{\circ} \mathrm{C}$. The endothermic peak at about $390^{\circ} \mathrm{C}$ was thought to be due to dehydration condensation in un-reacted part at $300^{\circ} \mathrm{C}$. It was difficult to clear the reason that the endothermic peak of dehydration reaction was split.

The system of $\mathrm{NH}_{4} \mathrm{H}_{2} \mathrm{PO} 4$ and $\mathrm{CuO}$ was less affected from mechanical treatment than the system of $\mathrm{NH}_{4} \mathrm{H}_{2} \mathrm{PO}_{4}$ and $\mathrm{CuCO}_{3} \cdot \mathrm{Cu}(\mathrm{OH}) 2 \cdot \mathrm{H} 2 \mathrm{O}$. These mechanical effects followed previous reports that mechanochemical effects are related with constitutive property of anion. 13,17

\section{Hue of various copper phosphates}

Figure 7 shows UV-Vis reflectance spectra of samples prepared from $\mathrm{NH} 4 \mathrm{H}_{2} \mathrm{PO} 4$ and $\mathrm{CuCO} 3 \cdot \mathrm{Cu}(\mathrm{OH}) 2 \cdot \mathrm{H} 2 \mathrm{O}$ in $\mathrm{P} / \mathrm{Cu}=2 / 3$ milled for several minutes and then heated at $700^{\circ} \mathrm{C}$. The intensity of reflectance at $400-600 \mathrm{~nm}$ was strong in samples milled for 20 and $30 \mathrm{~min}($ Fig. 7(c)(d)). As mechanochemical effects, UV-Vis reflectance spectra were changed and samples had vivid tone. Samples prepared from $\mathrm{NH}_{4} \mathrm{H}_{2} \mathrm{PO} 4$ and $\mathrm{CuO}$ were generally a little gloomy because of the dark tone of unreacted $\mathrm{CuO}$.

Figure 8 shows particle size distribution of samples prepared from $\mathrm{NH} 4 \mathrm{H} 2 \mathrm{PO} 4$ and $\mathrm{CuCO}_{3} \cdot \mathrm{Cu}(\mathrm{OH}) 2 \cdot \mathrm{H} 2 \mathrm{O}$ milled for several minutes and then heated at $700^{\circ} \mathrm{C}$. The mean particle sizes in Fig. 8 were (a) 3.7, (b) 16.4, (c) 24.6 , and (d) $33.4 \mathrm{~m}$. The large part of sample powder was the size range from 0.5 to $300 \mathrm{~m}$. The particle size distribution of samples in $\mathrm{P} / \mathrm{Cu}=2 / 3$ (Fig. 8(a)(b)) was consisted of two normal distribution. The maximum frequency at about $30 \mathrm{~m}$ became larger by mechanical treatment. The particle size distribution of samples in $\mathrm{P} / \mathrm{Cu}=2 / 1$ (Fig. 8(c)(d)) was consisted of three normal distribution. Particle size of samples in this ratio became large by mechanical treatment. As mechanochemical effects, 
materials were much sintered. Furthermore, all samples had smaller specific surface area than $10 \mathrm{~m}^{2} \cdot \mathrm{g}^{-1}$ in spite of milling time.

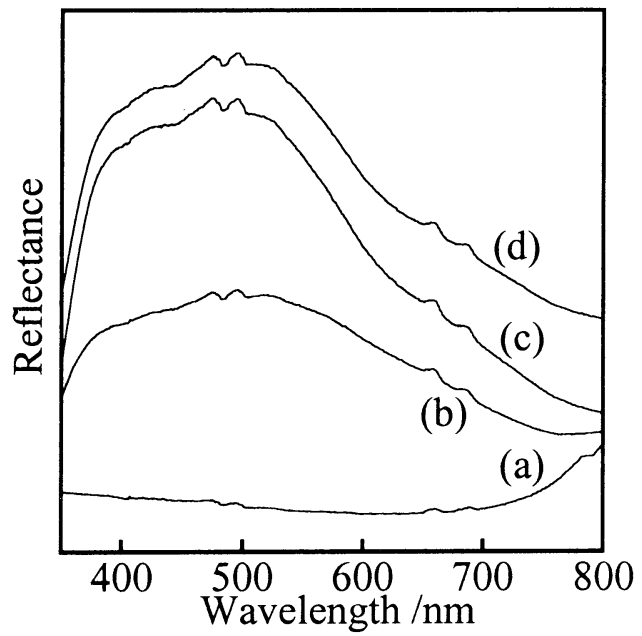

FIGURE 7. UV-Vis reflectance spectra of samples prepared from $\mathrm{NH} 4 \mathrm{H} 2 \mathrm{PO} 4$ and $\mathrm{CuCO}_{3} \cdot \mathrm{Cu}(\mathrm{OH}) 2 \cdot \mathrm{H} 2 \mathrm{O}$ in $\mathrm{P} / \mathrm{Cu}=$ $2 / 3$ milled for several minutes and then heated at $700^{\circ} \mathrm{C}$, (a) $0 \mathrm{~min}$, (b) 10 min, (c) $20 \mathrm{~min}$, and (d) $30 \mathrm{~min}$.

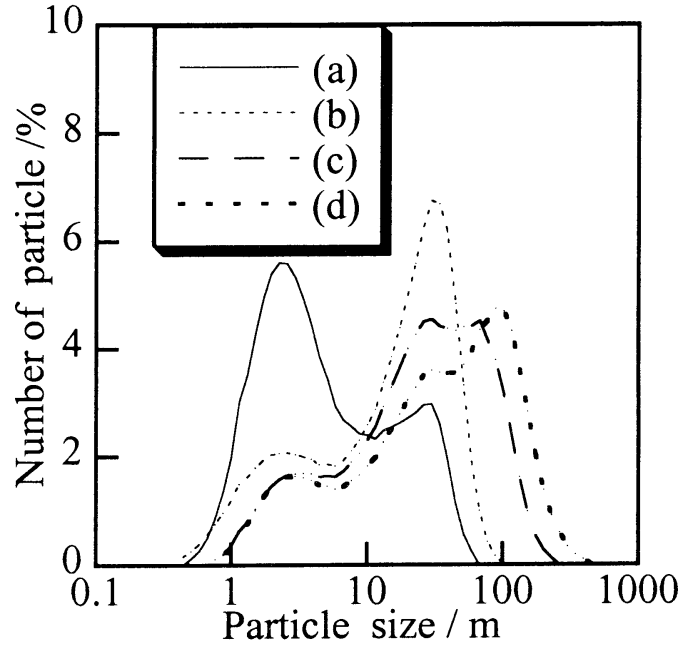

FIGURE 8. Particle size distribution of samples prepared from $\mathrm{NH}_{4} \mathrm{H}_{2} \mathrm{PO} 4$ and $\mathrm{CuCO}_{3} \cdot \mathrm{Cu}(\mathrm{OH}) 2 \cdot \mathrm{H}_{2} \mathrm{O}$ milled for several minutes and then heated at $700^{\circ} \mathrm{C}$, (a) in $\mathrm{P} / \mathrm{Cu}=2 / 3,0$ min, (b) in $\mathrm{P} / \mathrm{Cu}=2 / 3,30 \mathrm{~min},(\mathrm{c})$ in $\mathrm{P} / \mathrm{Cu}=2 / 1$, $0 \mathrm{~min}$, and (d) in $\mathrm{P} / \mathrm{Cu}=2 / 1,30 \mathrm{~min}$.

\section{CONCLUSION}

Mechanochemical effects were investigated on formation and properties of various copper phosphates in the system of $\mathrm{NH}_{4} \mathrm{H}_{2} \mathrm{PO} 4$ and $\mathrm{CuCO}_{3} \cdot \mathrm{Cu}(\mathrm{OH}) 2 \cdot \mathrm{H}_{2} \mathrm{O}$ and the system of $\mathrm{NH}_{4} \mathrm{H}_{2} \mathrm{PO}_{4}$ and $\mathrm{CuO}$. Thermal products were changed by mechanical treatments. These were considered that starting materials were homogenized and activated as mechanochemical effects. The system of $\mathrm{NH}_{4} \mathrm{H}_{2} \mathrm{PO}_{4}$ and $\mathrm{CuO}$ was less affected from mechanical treatment than the system of $\mathrm{NH}_{4} \mathrm{H}_{2} \mathrm{PO}_{4}$ and $\mathrm{CuCO}_{3} \cdot \mathrm{Cu}(\mathrm{OH}) 2 \cdot \mathrm{H}_{2} \mathrm{O}$. Mechanochemical effects in this work are related with constitutive property of anion. Furthermore, as mechanochemical effects, UV-Vis reflectance spectra of various copper phosphates were changed and the samples had vivid tone. Mechanochemical treatment on starting materials had much influence on formation and properties of functional inorganic materials. 


\section{REFERENCES}

1. M. Tsuhako, S. Ikeuchi, T. Matsuo, I. Motooka, and M. Kobayashi, Bull. Chem. Soc. Jpn., 52, 1034 (1979).

2. H. Onoda, H. Nariai, H. Maki, and I. Motooka, Mater. Chem. Phys., 73(1), 19 (2002).

3. H. Onoda, H. Nariai, A. Moriwaki, H. Maki, and I. Motooka, J. Mater. Chem., 12(6), 1754 (2002).

4. H. Onoda, H. Nariai, H. Maki, and I. Motooka, J. Mater. Syn. Proces., 10(3), 121 (2002).

5. M. T. Averbuch-Pouchat and A. Durif, "Topics in Phosphate Chemistry" (World Scientific Publishing Co. Pte. Ltd., Singapore, 1996).

6. H. Onoda, H. Nariai, H. Maki, and I. Motooka, Phosphorus Res. Bull., 12, 139 (2001).

7. H. Y-P. Hong, Acta Cryst., B30, 468 (1974).

8. W. Kim, Q. Zhang, and F. Saito, J. Mater. Sci., 35, 5401 (2000).

9. K. C. B. Yeong, J. Wang, and S. C. Ng, Biomater., 22, 2705 (2001).

10. K. Kudaka, K. Iizuka, T. Sasaki, and H. Izumi, J. Am. Ceram. Soc., 83, 2887 (2000).

11. H. Nariai, M. Tada, M. Tsuhako, and I. Motooka, Phosphorus Res. Bull., $\underline{5}$, 125 (1995).

12. H. Nariai, S. Shibamoto, H. Maki, and I. Motooka, Phosphorus Res. Bull., $\underline{8}$, 101 (1998).

13. H. Onoda, H. Nariai, H. Maki, and I. Motooka, Mater. Chem. Phys., $\underline{78(2)}$, 400 (2002).

14. H. Onoda, H. Nariai, H. Maki, and I. Motooka, Phosphorus Res. Bull., 9 , 69 (1999).

15. H. Onoda, N. Sugino, K. Kojima, and H. Nariai, Mater. Chem. Phys., 82(3), 831 (2003).

16. D. E. C. Corbridge and E. J. Lowe, J. Chem. Soc., 493, 4555 (1954).

17. M. Quatinetz, R. J. Schafer, and C. R. Smeal, NASA Tech. Note, D-879 (1962). 